\title{
TAXATION: A VERITABLE INSTRUMENT FOR THE COERCED PROLETARIANIZATION OF THE BEROM PEOPLE OF NORTHERN NIGERIA, 1902-1960
}

\author{
Daniel Datok Dalyop \\ Shakila Parween Yacob
}

\begin{abstract}
The pre-colonial Berom societies were peaceful, self-reliant and self-sustaining. They are blessed with huge deposits of natural resources i.e. tin ore, columbite, wolfram and tantalite. Taxation was alien and non-existent in the pre-colonial Berom societies. It was introduced and imposed by the British colonial government after the conquest and subjugation of the Berom people. This conquest and subjugation began in the year 1902 and successfully opened up Berom land for the commencement of an era of expansive and intensive tin mining activities. The colonial administration and mining activities came to an end on $1^{\text {st }}$ October, 1960 with the attainment of political independence by Nigeria. This article examines the use of taxation as a strategy that was adopted by the British colonial government to coerce the Berom people to the tin fields and supply the necessary and indispensable labour-force that was in high demand. The pre-colonial Berom people practiced subsistence agriculture as the main-stay of their economy and did not possess the requisite skills needed for commercial and modern techniques of tin mining activities. Hence they were employed as un-skilled labour-force. They were paid stipend in the form of wages which they used for the payment of the heavy taxation imposed on them by the British colonial government, and for the sustenance of their livelihood. These wages were very meagre and had dire consequences. It resulted into massive impoverishment of the people and relegated them to a life of hunger and penury.
\end{abstract}

\section{Introduction}

The major pre-colonial economy of the Berom people was agriculture. They cultivated their food crops on a subsistence basis. Although a small number of the people were engaged in tin mining activities on a subsistence basis too. The discovery of tin ore by the British government hastened the commencement of the conquest and subjugation of Berom land in 1902. Tin ore was the major reason for British presence. By 1906, many Berom villages had been conquered and opened up for tin mining activities. The stiff resistance of the people who used crude weapons, could not stand the strong fire-power of the Maxim gun and the resolutely determined and fierce British forces known as the West African Frontier Force (WAFF).

After the conquest of Berom land by 1906, the British declared it as Crown land. The people were divorced and alienated from the possession of their land and its natural resources. This declaration ushered in an era of intensive and expansive activities of tin mining. Numerous multinational companies and rich private capitalists were attracted into Berom land, to establish their presence and exploit the huge deposits of tin, columbite and other natural resources. The tin mining activities were labour-intensive that required a large number of labour-force. The multinational tin mining companies had expected to acquire the inevitable labour-force from the 
Berom people, on whose land the tin mining activities were on-going. But the Berom people were indifferent and refused to supply the labour-force. This was basically because of the brute force used to conquer them and the fact that they had suddenly become landless peasants due to the seizure of their land and its subsequent declaration as a Crown land. The British colonial government took charge of the appropriation and expropriation of the Crown land. The crown land policy was already in existence in the larger northern region of Nigeria which Berom land is a part of.

The British colonial government in its desire to ensure the immediate take-off of tin mining activities and the supply of labour-force, imposed heavy taxation on the Berom people. The essence was to coerce the Berom people to go and work on the tin fields. This was the only existing avenue that would enable them to earn the money to pay for their taxes. And also to enable the colonial government to generate the money needed for the running of the affairs of the colonial government. Therefore, the major thrust of this article is to examine and disclose the imposition and manipulation of heavy taxation as a strategy by the British colonial government to compel the Berom people to go to the tin fields and supply their labour-force in return for wages. This changed the occupation of the people from agricultural practices to proletarianization, which had adverse effect that led to the immiserisation of the people.

\section{Brief History of Berom Land}

Berom land is situated on the Jos Plateau which is located in the Northern region of Nigeria. It is blessed with huge deposits of tin ore, columbite, tantalite and wolfram among others. In fact, it is the only tin field in the world where tin and columbite were mined simultaneously. ${ }^{1}$ It is popularly known as 'Tin City' because of the massive tin mining activities that was carried out during the colonial era in Nigeria. It lies between latitudes 7 degree and 11 degree north and longitudes 7 degree and 25 degree east. It has an average height of 1,200 meters above the sea level. ${ }^{2}$ It is peculiar and different from the other parts of Nigeria, because its physical features are dominated by mountains, rocks and hills from where its name was coined. ${ }^{3}$ Though located in the tropical region, it has a near temperate climate. The yearly temperature of the Jos Plateau ranges from 50 to 90 degrees Fahrenheit, which makes it one of the known coldest part of Nigeria. ${ }^{4}$

The name 'Berom' does not have a particularly identified meaning. It has been suggested to mean the plural form of the name of the founder and mythical ancestor of the Berom people. The singular name is known as Worom. ${ }^{5}$ 
Figure 1: Map of Nigeria Showing the Location of Berom Land

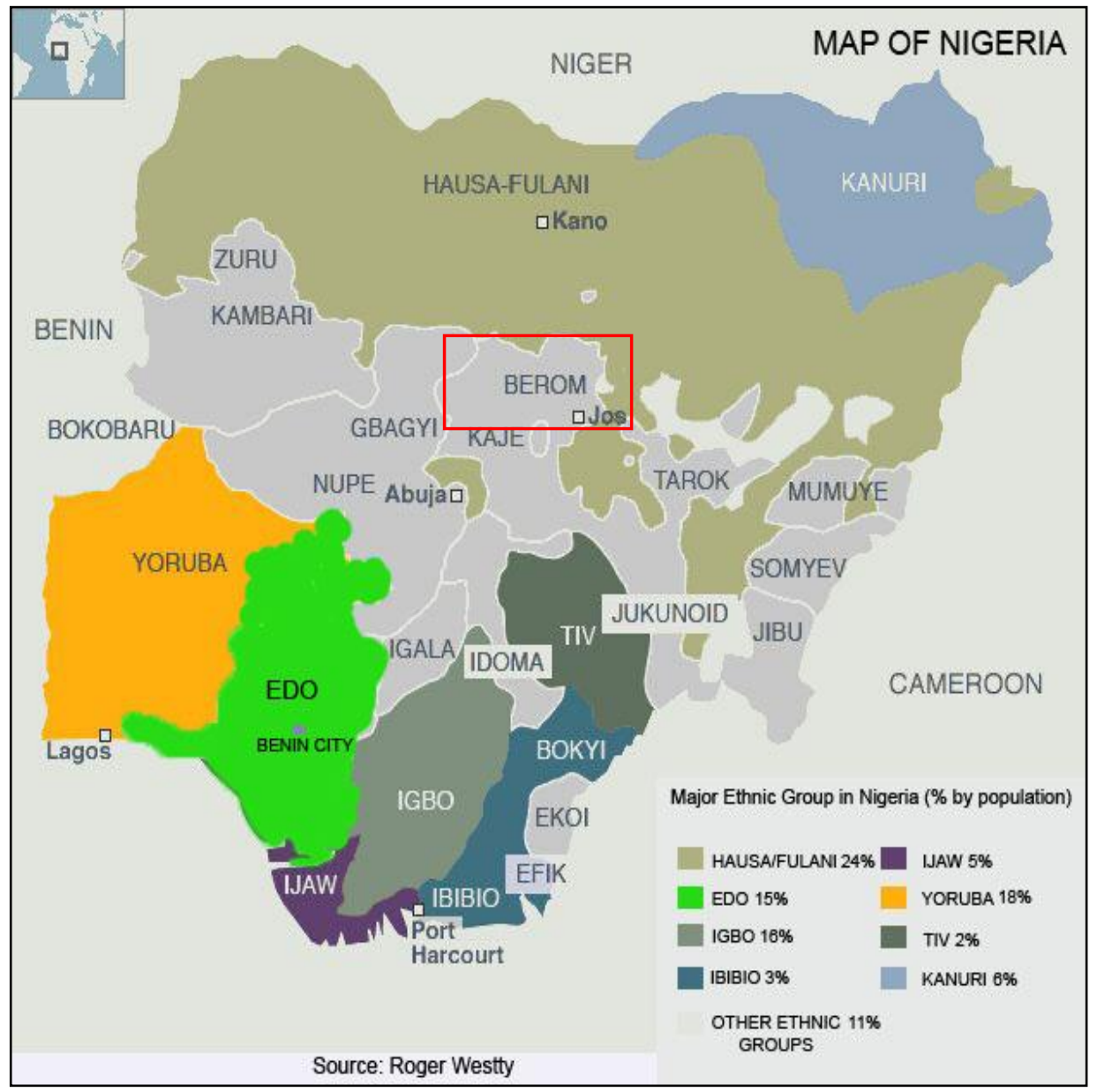

Source: https://www.google.com (accessed on 3 January 2017).

The embracing atmosphere of the Jos Plateau and its scenic beauty leaves a lasting impression on the Europeans as one of the healthiest places in West Africa. ${ }^{6}$ Little wonder it had the largest number of Europeans in the whole of West Africa. People from other parts of Nigeria and Africa have been attracted to the Jos Plateau for tin mining activities, business and re-settlement as the case maybe, hence it is cosmopolitan nature. It served as an administrative center since the colonial era and is currently the capital of Plateau state, which is one of the 36 states of Nigeria. ${ }^{7}$ The Jos Plateau is made up of three major indigenous ethnic groups which are the Berom, Anaguta and Afizere people. The Berom people constitutes the largest population and the preponderance of tin mining activities were carried out on their land. For example, 800 out of the 1,000 abandoned tin mining ponds on the Jos Plateau tin fields are located in Berom land. ${ }^{8}$

\section{Conceptual Framework}

A one-time colonial governor general of Nigeria, Lord Frederick Lugard, was of the opinion that it was imperative to pay money to those whose labour-force have been engaged. And in return collect back the money from them in the form of taxes and tributes. He further stated that this action would certainly teach and enlighten the 
people on the fact that their labour-force was paid for, and that the payment of taxes was inevitable and compulsory. ${ }^{9}$

Lugard looked at taxation as an exercise which is morally and psychologically beneficial to the populace. It is a pivot for the encouragement and stimulation of productive and industrial ability of the populace. ${ }^{10}$ Mwangi Wambui stated that taxation connotes a consistent relationship characterised by subjugation and domination. ${ }^{11}$ People who default in the payment of their taxes are usually sanctioned and penalised to serve as a deterrent to others.

The word proletarianization was made popular by the German philosopher and economist called Karl Marx which generated a lot of controversies all over the world. It is pertinent to state here that this article shall not delve into arguments and counterarguments, 'pros and cons' of class formation as propounded by Karl Marx. The article intends to limit itself to the literal meaning of the word, and its application to the history of the Berom people. Proletarianization is the benchmark and beginning of production and the accumulation of wealth in the capitalist societies.

Proletarianization is known to be the long tradition of separating the people who manufacture products from the lawful source which they use to manufacture the products. This in turn produces a group of people who are enriched by the fact they retain profits from their possession of resources or capital. This group of people are called the bourgeoisie. ${ }^{12}$ While those group of people who are poor and have no resources or capital, produces the profits and receive stipends in the form of wages are called the proletariats. The only means of livelihood and survival open to the proletariats, is the sale of their labour-force in exchange for pittance in the form of wages. $^{13}$

Proletarianization can also be defined as an increase in the number of the populace that have been cut-off and deprived from the possession of any means of production. The only choice left to them to survive is the exchange of their energies for money with the big companies and rich individual capitalists. ${ }^{14}$

Proletarianization according to Deborah Bryceson is the complete separation of the producers from their legitimate property, which had hitherto given them material and social satisfaction. Subsequently, the only choice available to them is the transaction of their labour-force for money. ${ }^{15}$ As earlier stated, these concepts would lay the basis for our study on the use of taxation as a veritable tool under the control of the colonial government, which led to the coerced proletarianization of the Berom people on the Jos Plateau tin fields.

\section{Taxation in Other British Colonies}

The imposition of taxation was an economic policy and strategy adopted by the British colonial government and was not peculiar to Berom land alone. It was widely practiced and implemented in the governance and administrative structure of British colonies or empire in particular, and among members of the commonwealth in general. However, there were some level of differences in the level of autonomy and implementation of taxation policies in the British colonies. For example, Canada, New Zealand, South Africa and Australia enjoyed a very high degree of autonomy in the administration and collection of their taxes. This was basically because they operated a quasi-independent colonial or 'white-settler' government in their colonies known as dominion. But other British colonies i.e. Gambia, Ghana, Nigeria and Sierra 
Leone were directly controlled from a centralised colonial office in London which also determined and fixed their taxes. ${ }^{16}$

Barbara and Josephine opined that two major purposes were achieved by the colonial economy from the imposition of taxation on the British colonies. Firstly, the indigenous people of Africa were forced to pay the cost of running the colonial government and take responsibility for the privilege of having a 'white' colonial government. And secondly, the imperative need to earn money for the payment of their taxes, compelled Africans to become employees who worked on the cash crop plantations and the mining sectors. ${ }^{17}$

In the same vein, George Beer Louis, the United States expert at the victorious allied powers Peace Conference which took place in Versailles in 1919 was quoted by Barbara and Josephine to have said that the major essence for the political and economic intervention, and the various colonial government's presence in the African continent was simply to take control, direct and manage one of the 'Chief Asset' of Africa, which was the labour-force of its people. ${ }^{18}$

The British colonial government insisted that the Berom people must pay their taxes in the British currency. This insistence could be deduced from the statement by the Lord Chalmer during the Order-in-Council in 1825 in Great Britain where he asserted that the British currency should be supplied and circulated throughout the world where the sound of the British drum could be heard. ${ }^{19}$ The above statement by Lord Chalmer left an impression on those saddled with the affairs of the British colonial government.

There are some reasons that have been advanced as the major essence for the introduction and circulation of the British currency as legal tender in its colonies. Firstly, the British currency in West Africa where Berom land is located, was meant to raise the money that was very necessary to off-set the salary and allowances of the British staff in the colonies i.e. civil servants, administrators and the armed forces personnel who were responsible for the pacification and conquest of more territories. ${ }^{20}$ Secondly, the British currency was meant to be a strategy that would ensure that the cost of intra-empire transactions were reduced for both the private and public business organisations. Thirdly, it was meant to serve as a motivation, inducement and encouragement that would push the wealthy British capitalists and other private businesses to participate and establish their presence in the British colonies. ${ }^{21}$ And fourthly, the essence of the British currency was meant to ameliorate or eliminate the impediments hindering easy access as a result of increased economic and business activities between Great Britain and her colonies i.e. Berom land. ${ }^{22}$ The British currency was also introduced and circulated in her colonies as a legal tender to ensure total control of its value and uses. And also as a strategy to ensure that they had total monopoly over the administration and economy of her colonies.

The Lord Lewis Harcourt who was the British Colonial Secretary, set up the Lord Emmot Committee which became widely recognised as the West African Currency Committee in 1911. By June 1912, the Emmot committee submitted its report which recommended the establishment of a board that would take charge of currency issues in West Africa. Based on this recommendation, the West African Currency Board (WACB) was formed in November 1912. ${ }^{23}$ The WACB became responsible for the introduction, supply, control and circulation of the British currency i.e. pound sterling and shillings in West Africa. The WACB was also saddled with the duty to handle all other currency issues that involved the British colonies and protectorates in West Africa i.e. Gold Coast (Ghana), Gambia, Sierra Leone and Nigeria. ${ }^{24}$ However, it is imperative to state here that the introduction and circulation 
of the British currency as a legal tender in Berom land, was a viable and contributory factor in the coerced proletarianization of the Berom people who became wage earners on the tin fields. This was because the poor and unskilled people could only earn the British currency by working as proletariats on the tin fields.

In another development, this article argues that the imposition of heavy taxation by the British colonial government was a viable and portent strategy that succeeded in compelling the indigenous people of Africa to become proletariats. They worked and toiled very hard to earn the British currency which they used to off-set their taxes. It was earlier mentioned that the imposition of heavy taxation by the British colonial government was not restricted to Berom land, as it was a common practice among the British Empire. This article shall consider two succinct examples. First, in the British colonies of Sierra Leone, which is located in West Africa and was initially made up of freed slaves from Europe i.e. Britain. Secondly, in Witwatersrand, located in South Africa, Southern Africa.

In Sierra Leone, the British colonial government imposed a high and burdensome tax known as 'hut-tax' on the people. And the colonial government further ensured that the collection of the 'hut-tax' was uncompromisingly and harshly enforced. The poor people of Sierra Leone had no money to off-set their taxes. Therefore, the only option opened to them was to get into a transaction with the wealthy Europeans, where they were engaged to do menial jobs that were labour intensive in return for money which they used for the payment of their taxes. ${ }^{25}$

The second illustration where taxation was adopted and used by the British colonial government to mobilise forced labour was in Witwatersrand, South Africa as earlier enumerated. The town of Witwatersrand, South Africa is blessed with a large deposit of natural gold. During the period within the 1880s, the rich European capitalists who forcefully became the goldmine owners had intensified and expanded gold mining activities in Witwatersrand. They adopted and manipulated the imposition of taxation as a major strategy to coerce the un-willing people of Witwatersrand to go to and supply the much needed labour-force on the goldmines. ${ }^{26}$ The imposed taxes on the people included cattle taxes, hut taxes, dog taxes and horse taxes. They made sure that these taxes were strictly adhered to and could only be paid using cash. The poor and unskilled people of Witwatersrand could only earn the money for the payment of their taxes through the supply of their labour-force to the goldmines in return for wages. ${ }^{27}$

In Witwatersrand, one of the compulsory conditions to be met before the payment of tax could commence by the young adults was fixed upon the attainment of the age of 15. The essence of the reduction in age was to ensure that a larger number of African labour-force as possible was mobilised to work on the goldmines. By the year 1910, there had been the successful establishment and institution of a system of forced labour in Witwatersrand. This left the people with no better alternative as they were forcefully and successfully mobilised from the hinterland to go and work on the goldmines. ${ }^{28}$ These are two succinct accounts of the imposition and use of taxation by the British colonial government to force the people of Sierra Leone and Witwatersrand, South Africa to exchange their labour-force in return for the wages needed for the payment of their compulsory taxes. 


\section{The Imposition of Heavy Taxation in Berom Land}

The colonial government anxious to extract tax money from the Berom people, were somewhat sympathetic and from 1909 actually ensured that tax money would come from mines labour. The Berom people were provided with minimum time needed for the payment of their taxes. ${ }^{29}$ By the year 1915, the District officers were instructed by the colonial government to inform the local chiefs of the people that mines labour was the best way to earn the tax that had to be paid. ${ }^{30}$ At first the colonial government hungry for taxes, pushed for the collection of tax when it stated that:

It is believed in taxation as a means of reducing the people to work and turn the products of their country to account... So much money will be placed in circulation by the mines that we must expect, not only that taxes will all be collected in cash, but we must also look for a great increase. $^{31}$

Speaking for the Niger Company in the early 1920s, Henry Laws opposed organised recruitment schemes and doubted that non-Muslim communities i.e. the Berom people in the vicinity of the mines could supply the cheap abundant labourforce of which the mines companies dreamed, without destroying their agricultural systems. He believed that the most efficacious means for developing a labour supply was indirect government aid, such as direct and much heavier taxation, compelling the idlers, of which there were many, to supply their labour-force to the tin fields. ${ }^{32}$

In another development, the conquest and subjugation of the Berom people by the British forces opened up their land and tin mining activities began in earnest. The multinational companies that moved in to participate in the tin mining activities, relied on the Berom people to provide the labour-force that was required on the tin fields. But the Berom people were indifferent and apathetic due to their travails in the hands of the British forces, WAFF and the confiscation of their land which was immediately declared as crown land. The seizure of the people's land completely incapacitated them because it was hitherto the main-stay of their economy. Therefore, they refused to supply the required labour-force to the tin fields. This is evident by a letter written in the year 1907 by Growers, a colonial official to the Naraguta tin mining company which stated as follows:

I do not intend to compel the pagans to go and work for you on your tin fields, because there is no forced labour as you are aware. But the payment of tax by the pagans is mandatory, therefore the Assistant Resident stationed at Bukuru district will have to use his influence to convince and induce the pagans to obtain their tax in the easiest and only means accessible to them, that is by working as labourers on the tin minefields and serving as human porters who would transport tin. ${ }^{33}$

The above statement by Growers is a confirmation of the fact that the colonial government had a clear-cut intention of manipulating and influencing the imposition of taxation to push the Berom people into becoming proletariats on the tin fields. It is also pertinent to point out here that the Berom people were un-skilled and could only be employed to the lowest rung of the mining activities as labourers on the tin fields. However, the people were vehemently adamant to work on the tin fields. This was mainly because of the brutalisation they under-went in the hands of the colonial 
forces. And also the fact that they suddenly became landless peasants due to the confiscation and declaration of their land as crown land as earlier noted.

The taxes paid by the Berom people were referred to as 'tributes.' And the colonial government made the payment of tax mandatory on every male Berom youth who had attained the age of 16 years and above. ${ }^{34}$ It is pertinent to point out here that the age of 16 that was applied for the Berom youths was at variance with the acceptable age of 18 that was acceptable in Europe, America and other developed societies. The essence was to ensure that the most strong and vibrant Berom youths were coerced to go and supply the highly demanded labour-force on the tin fields in order to earn the money needed for the payment of their taxes. The documents in the Nigerian archives clearly shows that the major thrust for the introduction of taxation in Berom land was to coerce the people to supply their labour-force to the tin fields. For example, the colonial Resident of Bauchi province issued a statement in the year 1919 where he stated that:

I do not believe in forcing pagan labour to the tin mines. But I do think it justifiable to take all the necessary measures through taxation which will indirectly have the desired effect. ${ }^{35}$

The statement by the colonial Resident of Bauchi province clearly depicts and confirms the major purpose for the introduction, imposition and enforcement of taxation in Berom land. Taxation usually have the backing of the law. And people who default in the payment of their taxes were usually sanctioned according to the provisions of the law. This made it very convenient for the colonial government to impose and enforce taxation.

The manipulation of taxation for the coerced proletarianization of the Berom people is succinctly contained in an archival document in the year 1919, when a colonial officer, His Excellency A.G. Boyle made the following statement:

The chamber of mines was unanimous in its opinion that the pagans would only work if higher taxation was imposed, and that the present rate is too low. They said that in view of the fact that the pagans as a rule work for three of four days in order to obtain their tax, it would be no hardship nor unfair to them to impose a heavier tax. The approximate tax per adult male was $3 / 10 \mathrm{~d}$ and it might well be increased by from $25 \%$ to $50 \%$ i.e. to $4 / 9 \mathrm{~d}$ to $5 / 9 \mathrm{~d} .{ }^{36}$

The arbitrary increment by the colonial government in the amount of tax to be paid was aimed at ensuring that more people will find it a herculean task to pay their taxes. This invariably meant that those proletariats who were already employed on the tin fields, would have to spend more time on the tin fields in order to earn the money that they would need to pay their taxes. While those not employed on the tin fields were compelled to go and seek employment on the tin fields, at-least to earn the money for the payment of their taxes to avoid penalties from the colonial government.

Furthermore, a document accessed from the National Archives Kaduna, Nigeria vividly confirms the fact that the imposition of heavy taxation was solely targeted at the Berom people. They were the target because being the genuine and initial land owners, who resided within the jurisdiction of the tin mining activities, they were expected to be the first people to supply the required work-force on the tin 
fields. But they were not forth-coming in the supply of their labour-force to the tin fields.

The Colonial Secretary of the Northern region of Nigeria, G.R. Mathew, wrote a confidential letter to the Secretary of the Nigerian Chamber of Mines in the year 1919. Excerpts from the letter reads:

I am to say that the increase in taxation which it is proposed to effect, is not an increase in the tax paid by the mines' labourers already employed on the minefields, but in the taxation of the pagan areas of the Jos division...it is however, hoped that the measures will have the effect of encouraging the flow of pagan labour to the minefields. ${ }^{37}$

There are more confidential letters written by the colonial officials on the need to use taxation to manipulate and coerce the Berom people to become proletariats on the tin fields.

In the same vein, a correspondence written in the year 1919 by the Secretary of the Local Council of the Nigerian Chamber of Mines addressed to the Secretary of the Northern Province, unambiguously stipulated that:

We believe that an increase of 50 percent on the pagan taxes would encourage a greater number to seek employment on the mines and to remain there for a longer periods of time. ${ }^{38}$

These statements by the colonial officials is a clear reflection of their intentions for the imposition and consistent increment of taxation in Berom land. The major intention as has been disclosed, was to coerce the Berom people to supply the necessary labour-force that was in high demand at the tin fields. And also to remain on the tin fields for an unspecified period of time. In fact, the colonial government was obsessed with exacting cash taxation on the Berom people. The local chiefs and other trustworthy people were appointed and saddled with the responsibility of tax collection. In most cases, these tax collectors were accompanied by police patrols. ${ }^{39}$

The imposition of heavy taxation and its subsequent arbitrary increases on the Berom people, erroneously referred to as pagans as earlier noted, was a veritable weapon in the hands of the colonial government which was coercively put to use and it succeeded in transforming the Berom people into proletariats on the tin minefields. The table below shows the astronomical increase in the amount of taxation on the Jos Province.

Table 1: Tax Increase within the Jos Province, 1920-1965

\begin{tabular}{cc}
\hline Year & $\begin{array}{c}\text { Tax Rate in } \\
\text { Pounds/Shillings }\end{array}$ \\
\hline 1920 & $3 / 10$ \\
1939 & $4 / 1$ \\
1945 & $4 / 8$ \\
1949 & $7 / 4$ \\
1955 & $18 /-$ \\
1960 & $35 /-$ \\
1965 & $42 /-$ \\
\hline
\end{tabular}

Source: Sati Umaru, "The Colonial Economy and Society of Mupunland, 1907-1960", Master of Arts Degree, Department of History, University of Jos, December, 1991, p. 125. 
It is pertinent to point out here that the Jos Province had the highest amount of taxation when compared to the other provinces. For example, the collection of taxation in the year 1946 in the whole of the northern region of Nigeria was about 2,400 pounds and over 1,000 pounds of this amount was collected from Berom land. ${ }^{40}$ Table 1 depicts the rate of arbitrary increase in the amount of money to be paid by the poor and unskilled people, i.e. there was an increase from $£ 3$ in 1920 to $£ 35$ by 1960 . In fact, the people were dis-enchanted with the imposition and collection of heavy taxation. To ensure compliance and safety, the tax collectors had to be accompanied by police patrols in most instances. ${ }^{41}$

These have been supported by documents researched and acquired from the National Archives of Nigeria. For example, J.J. Emberton the Colonial Resident of the Plateau Province wrote a confidential letter in the year 1944 addressed to the Commissioner of Labour, Nigerian Secretariat Lagos, stated that:

Local pagans provide the bulk of the labour employed under the task system, their economy is such that they are almost entirely dependent on the mining industry for cash and they are therefore, in normal circumstances, forced to accept any wage, however low. I consider that steps should be taken to ensure that tasks are set of such a size as would enable a man working reasonably hard to earn a minimum sum of money. ${ }^{42}$

Emberton being the Resident of the Plateau Province, was a highly ranked British colonial officer. Official statements issued by him are believed to be the true representations and reflections of the colonial governments' policies and the province which he represented. Therefore, the above statement by him confirms the fact that the Berom people were successfully coerced into proletarianization. And they supplied the indispensable labour-force that was in great demand on the tin fields. It further attest to the fact that the Berom people were oppressed, manipulated and exploited, when it was stated that 'they are therefore, in normal circumstances, forced to accept any wage, however low. ${ }^{43}$ Further measures to squeeze and exploit the people are contained in the concluding part of Emberton's statement.

\section{Statistics on the Proletarianized Berom People}

It is imperative to commence by stating the fact that acquiring the population and the statistics of the proletarianized Berom people with precision would be a difficult task. This is simply because concerted efforts towards enumerating the Berom population was only started after the commencement of commercial tin mining activities. And the nature of tin mining activities where tributers were used. They did not maintain a comprehensive and coordinated register or statistics. And tin mining activities encouraged a massive influx of people into Berom land. This turned Berom land into a cosmopolitan city.

More so, census exercises are conducted in Nigeria without provision for ethnic identity or language affiliation. The essence is to foster national unity and cohesion. And also to discourage inter-ethnic rivalry and unhealthy competition. However, Hale Middleturn stated that the Berom tribe is the largest in population and occupies the eight southern districts and half of Ganawuri. ${ }^{44}$ Isichei corroborated with 
the position of Middleturn by stating that the Berom people are by far the most numerous people in the Jos division. ${ }^{45}$

Furthermore, Gunn stated that the comprehensive figures on the Berom population and density came from Davies, derived in turn from tax records of the mid-forties. It put the Berom population at 53,776 people. And that the Berom people are increasing in numbers at the rate of 1.5 percent annually. ${ }^{46}$ This population figure is not comprehensive because it excluded those members of the various villages who were not taxable, or who were by omission or commission not included in the tax register used to arrive at this number. In a seminar paper at the Department of History, University of Jos, Nigeria, Jacobs stated that the population of the Berom people had risen to about 74,977 and 82,746 people between 1944 and 1949 respectively. ${ }^{47}$ Mangvwat wrote that the population of the Berom people was 114, 033 by 1952 while Sen Luka Gwom stated that the Berom population was 192,881 people by the year $1963 .{ }^{48}$

Figure 1: The Number of Tax Payers in the Mid-1920s

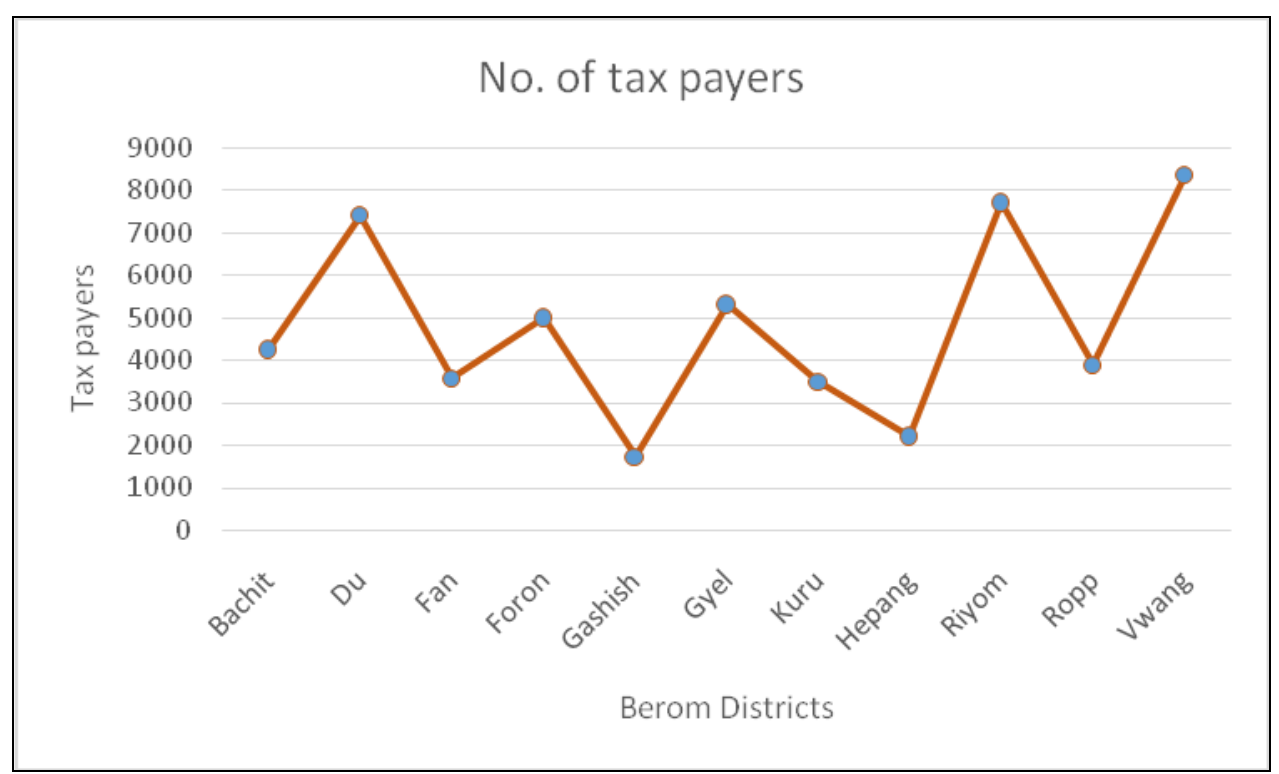

Source: NAK: JOS PROF 111, Annual Report of Plateau Province, 1926.

The imposition of heavy taxation left the people with no better alternative but to exchange their labour-force for wages. Figures 1 and 2 shows the statistics of tax payers from the different Berom districts in the mid-1920s and mid-1930s respectively. A total number of 50, 825 people and 52, 902 people were shown to have been paying their taxes between the mid-1920s and mid-1930s respectively. The highest number of 8,115 people paid their taxes from Vwang district because they had more population and were located closer to the tin fields. While 1,620 people from Gashish district who were less in population and farther away from the tin fields, paid their taxes as can be seen on Figure 1. 
Figure 2: The Number of Tax Payers in the Mid-1930s

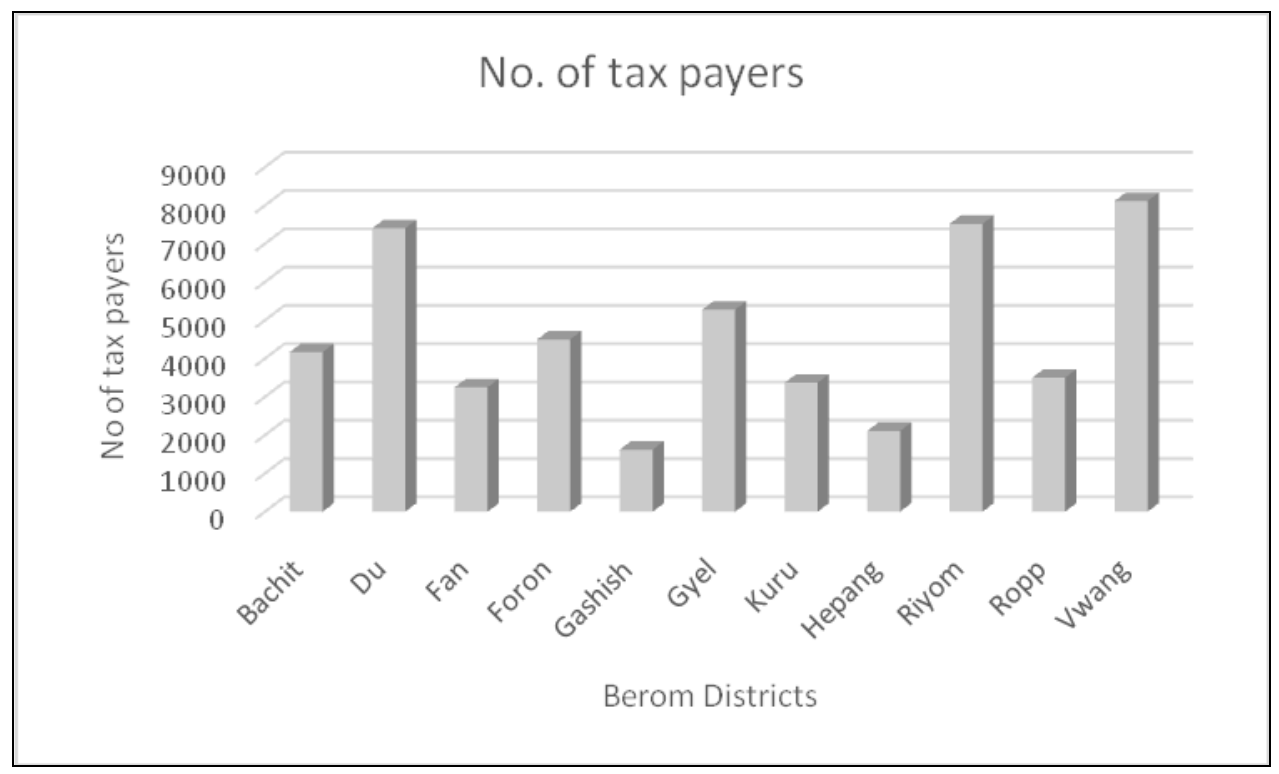

Source: NAK: JOS PROF 1/1, Annual Report of Plateau Province, 1936.

The Berom people were proletarianized because they were poor, not learned in the western education and unskilled. Hence they could only work on the tin fields as the only means to earn money without any better option available to them as earlier stipulated. There was increased tin mining activities in Berom land in the mid-1940s because the British colonial government had lost its richest tin producing colony of Malaya to the rampaging Japanese forces. ${ }^{49}$ The highest annual tonnage of 17, 463 was mined in 1943 at the peak of the Second World War. ${ }^{50}$ The Nigerian tin ore became more important to the British war efforts where tin mining activities and production were completely stepped up to augment for the loss of Malaya. ${ }^{51}$ In other words, Baker stated that so much pressure was exerted on the Berom labour-force i.e. the imposition of heavy taxation to work on the tin fields and produce the tin which had become so necessary to the allied forces since the failure of the Malayan supply. ${ }^{52}$ Tin was essential for the production of tanks and aeroplane engines, radio sets, antiaircraft devices, armoured cars and as packaging materials for oversea food to troops especially during the Second World War. ${ }^{53}$ 
Table 2: Population Derived by Davies from Tax-records of the Mid-forties

\begin{tabular}{|l|c|c|c|c|c|}
\hline $\begin{array}{c}\text { Berom } \\
\text { Districts }\end{array}$ & $\begin{array}{c}\text { Number of } \\
\text { Villages }\end{array}$ & $\begin{array}{c}\text { Number of } \\
\text { Tax Payers }\end{array}$ & $\begin{array}{c}\text { Area } \\
\text { (sq.m.) }\end{array}$ & $\begin{array}{c}\text { Density } \\
\text { (per sq.m.) }\end{array}$ & $\begin{array}{c}\text { Farmable acres per } \\
\text { adult factor }\end{array}$ \\
\hline Bachit & 7 & 4,347 & 63 & 69.0 & 6.7 \\
\hline Du & 7 & 7,609 & - & - & - \\
\hline Fan & 8 & 3,652 & - & - & - \\
\hline Foron & 11 & 5,072 & - & - & 29.5 \\
\hline Gashish & 5 & 1,689 & 109 & 15.5 & 4.4 \\
\hline Gyel & 4 & 5,391 & 75 & 119.8 & - \\
\hline Kuru & 2 & 3,598 & - & - & - \\
\hline Heipang & 6 & 2,238 & - & - & - \\
\hline Riyom & 7 & 7,781 & - & - & 3.3 \\
\hline Ropp & 7 & 3,985 & - & - & Average 6.4 \\
\hline Vwang/Vom & 4 & 8,414 & 57 & 47.6 & \\
\hline & 68 & 53,776 & & & \\
\hline
\end{tabular}

Source: Harold D. Gunn, Peoples of the Plateau of Northern Nigeria, London and Aylesbury: HazBill Watson and Viney Ltd., 1953, p. 77.

Invariably, the increase in tin mining activities in Berom land in the mid1940s also ensured a corresponding increase in the number of the proletarianized Berom people. This can be seen on Table 2 where a total number of 53, 776 Berom people paid their taxes in the mid-1940s. The imposition of heavy taxation which culminated into the successful proletarianization of the Berom people caused severe impoverishment, wide spread hunger and malnutrition. This view has also been shared by Mangvwat when he unambiguously wrote the following statement:

In addition to these terrible conditions under which the Berom people and others were subjected, as capitation tax rate was introduced in 1912, which required the Berom tin-bearing villages to pay $2 \mathrm{~s} 3 \mathrm{~d}$ per adult while those villages in the outlying areas of the mines paid only $6 \mathrm{~d}$ thereby coercing all taxable Berom people to flock the tin mines in search for tax money. And even as labourers on the tin mines the Berom people were invariably classified as the unskilled type and earned the lowest wages in the mines. In this way the Berom of the tin fields were constituted not only as the lowest class of people, but also the most desperate group in the colonial society of Jos Division and, indeed, the whole province. More than any group in the Plateau province, the Berom people of the tin-fields experienced the direct harshness and exploitation typical of colonialism in Plateau province. ${ }^{54}$

However, there were some positive developments that accompanied the expansive and intensive tin mining activities in Berom land. It opened up the area through economic growth and western civilisation. They provided socio-economic facilities to the area. For example, they were known to have been the first to have constructed and provided feeder roads, railways, electricity, schools, hospitals and portable water. More so, the success story of the tin-based multinational companies was an impetus that encouraged the influx of service-based multinational companies i.e. Paterson Zochonis (PZ), Leventis Motors, Lever Brothers, John Holt, Barclays 
bank, British bank for West Africa (BBWA) and British American Insurance Company among others.

Furthermore, some of the Europeans who went into Berom land for tin mining activities took advantage of the near temperate climate to introduce an array of exotic vegetables which had hitherto thrived in Europe. Some of the introduced exotic vegetables which are still cultivated at present includes cucumber, carrots, spinach, cabbages, lettuces and Irish potatoes among others. ${ }^{55}$ These were cultivated in the form of market gardening that was introduced in the 1910s. To cater for their dairy needs, the Europeans further took advantage of the climate to establish a dairy farm known as the Vom Dairy Industry in Berom land as early as in the year 1923. ${ }^{56}$

\section{Conclusion}

The major thrust and principle of proletarianization is reliant on the separation of the people from their legitimate source of production and livelihood. The people would then have no option but to become proletariats who would rely on the exchange of their energies to earn wages for their livelihood.

The principle of proletarianization was applied by the British colonial government in Berom land as this study has revealed. After the conquest and subjugation of the people, the colonial government declared Berom land as crown land. This declaration immediately separated and dispossessed the wholly agrarian Berom people of their land, which was the source of their food production and livelihood. The land dispossession was immediately followed by the imposition of heavy taxation as discovered in the study.

The twin-policies of land seizure and imposition of taxation succeeded in cutting-off the people from their legitimate source of food production. Subsequent upon these, the people were left with no other option but to seek employment on the tin fields as proletariats who worked very hard to earn the wages needed for the payment of their taxes. This was the major motive of the colonial government as this study has revealed. It was also discovered that the Berom people were coerced to the tin fields where they were employed into the lowest rung as un-skilled labourers and proletariats.

It is pertinent to state here that by $1^{\text {st }}$ October, 1960 when Nigeria got her independence from the British colonial government, an unquantifiable quantity of natural minerals i.e. tin ore and columbite had been mined and transported to Britain and other world markets from Berom land. The Berom people were left to wallow in penury. Their land have been destroyed and devastated by the open cast system of tin mining. At the moment, there are the preponderance of impoverishment and over 800 un-reclaimed abandoned tin mining ponds spread all over Berom land. These ponds are very dangerous and have been claiming both human and animal lives.

\section{Notes}

Bill Freund, Capital and Labour in Nigerian Tin Mines, London: Longman, 1981, p. 206. C.G. Ames, Gazetteer of Plateau Province, Jos Native Administration. London: Frank Cass and Company Ltd., 1934, p. 53. 
Z. Damina Goshit, "The Impact of the Great Depression on the Jos Plateau: A Case Study of the Mine Fields in the 1930s" Mandyeng Journal of Central Nigerian Studies, Department of History, University of Jos, 2001, p. 73. Central Nigerian Studies, Department of History, University of Jos, 2001, pp. 98-99. Watson and Viney Ltd., 1953, p. 75. It is important to point out here that the colonial government and administrators referred to the Berom people as 'pagans' as contained in the archival documents. This was because they did not belonged to either of the world's biggest religions of Islam and Christianity. However, they were not pagans in the real sense of the word because they had their own traditional religion which was also monotheistic in nature. Plotnicov Leonard, Strangers to the City, United States of America: University of Pittsburgh Press, 1967, p. 30. O. Cyril Imo, "Christian-Muslim Relations in Jos," pp. 98-99. Simon D. Mwadkwon, "Silencing the Spirit of the Shrine: The impact of Tin Mining on Berom Religion and Ecology," PhD thesis, Department of Religion, University of Jos, 2008, p. 11. Lord G. Frederick, 'Political Memoranda,' 1906, p. 214. Ibid. The writer of this article defines taxation as a mandatory amount of money that is imposed on corporate organisations and taxable adults by the government or its authorised agencies, which must be paid within a specified period of time and place. Mwangi Wambui, "Of Coins and Conquest: The East African Currency Board, the Rupee Crisis, and the Problem of Colonialism in the East African Protectorate", Comparative Studies in Society and History, Cambridge University Press, Vol. 43, No .4, October 2001, p. 781. John Langton, "Proletarianization in the Industrial Revolution: Regionalism and Kingship in the Labour Markets of the British Coal Industry from the seventeenth to the nineteenth Centuries", Transactions of the Institute of British Geographers, Vol. 25, No. 1, The Royal Geographical Society, 2000, p. 32. Ibid.

Hagan Koo, "From Farm to Factory: Proletarianization in Korea", American Sociological Review, Vol. 55, No. 5, American Sociological Association, October, 1990, p. 669. Deborah Fahy Bryceson, "The Proletarianization of Women in Tanzania", Review of African Political Economy, No. 17, Taylor and Francis Ltd., January-April, 1980, p. 4. Barbara Bush and Josephine Maltby "Taxation in West Africa: Transforming the Colonial Subject into the Governable Person", Elsevier, Critical Perspective on Accounting, Volume 15, Issue 1, January 2004, p. 12. Ibid., p. 21.

Ibid. A.H.M. Kirk-Greene, "Major Currencies in Nigerian History", Journal of Historical Society of Nigeria, Vol. 2, No. 1, 1960, p. 132. Walter Ofonagoro, Trade and Imperialism in Southern Nigeria 1881-1929, Nok Publishers, 1979, pp. 10-12. Eric Helleiner, "The Monetary Dimensions of Colonialism: Why Did Imperial Powers Create Currency Blocs?", Geopolitics, Frank Cass, London, Vol. 7, No. 1, Summer 2002, p. 7. Dan O. Chukwu, "Trends and Changes in the Nigerian Currency System, Colonial Period to 2008", Kamla-Raj, Stud Tribes Tribals, Vol. 8, No. 2, 2010, p. 91.

Ibid.

Ibid.

Stephen Ocheni and Basil C. Nwankwo, "Analysis of Colonialism and Its Impact in Africa", Cross-Cultural Communication, Canadian Academy of Oriental and Occidental Culture, Vol. 8, No. 3, 2012, pp. 49-50. Moitsadi Moeti, "The Origins of Forced Labour in the Witwatersrand," Phylon, Clark Atlanta University, Vol. 47, No. 4, $4^{\text {th }}$ Quarter, 1986, p. 276.

Ibid., p. 279.

Ibid., p. 276.

Bill Freund, Capital and Labour in Nigerian Tin Mines, p. 55.

Ibid.

Ibid., p. 57.

Ibid., p. 75. 
Naraguta Tin Mines, First File of Letters, No. 895/1907 'Letter from Gowers to Archbold' $25^{\text {th }}$ July, 1907, Jos Museum, Jos Plateau State, Nigeria.

National Archives Kaduna, Nigeria (henceforth written as NAK) and Secretariat, Northern Province Kaduna, Nigeria (henceforth written as SNP) NAK: SNP 10, 251P, 1919 'Labour for Mines, Increase Taxation in Jos division and other Pagan Areas, 1919.

NAK: SNP 658/1919 'Bauchi Province, Provincial Administration, Political, $11^{\text {th }}$ August, 1919.

NAK: SNP 10/7/251P/ 1919 'Labour for Mines, Increased Taxation in Jos division, $9^{\text {th }}$ July, 1919.

NAK: SNP Confidential Letter No. 251P/1919 'Written by the Secretary Northern Province to the Secretary Nigerian Chamber of Mines' $6^{\text {th }}$ October, 1919.

NAK: SNP Confidential Letter from the Secretary, Local Council of Nigerian Chamber of Mines to the Secretary, Northern Province Kaduna, $27^{\text {th }}$ September, 1919.

Bill Freund, Capital and Labour in Nigerian Tin Mines, p. 87.

NAK: SNP 39983, Confidential No.252/10, 'Development of the Berom Tribal Area,' $6^{\text {th }}$ February, 1946.

Bill Freund, Capital and Labour in Nigerian Tin Mines, p. 87.

NAK: Confidential Letter No. C220/33 'Labour Conditions on the Minefields' $8^{\text {th }}$ September, 1944.

NAK: Confidential Letter No. C220/33 'Labour Conditions on the Minefields' $8^{\text {th }}$ September, 1944.

Middleturn H. Hale, Plateau Province of Nigeria from 1926 to 1934, Jos Nigeria: Niger Press, 1942 , p. 54.

Elizabeth Isichei (ed.), Studies in the History of Plateau State Nigeria, London: The Macmillan Press Ltd., 1982, p. 12.

Harold D. Gunn, Peoples of the Plateau of Northern Nigeria, p. 77.

Charles C. Jacobs, "The Land Question: Tin Mining and the Berom Resettlement Scheme at Sabon Zawan 1945-1955", Seminar Paper presented at the Department of History, University of Jos, $6^{\text {th }}$ March, 1986, p. 1.

Gwom S. Luka, The Berom Tribe of Plateau State Nigeria, Jos Nigeria: Fab Anieh Ltd., 1992, p. 17. The Japanese forces invaded Malaya on the $8^{\text {th }}$ December, 1941 , and by $15^{\text {th }}$ February 1942 had conquered the entire Malay peninsula and secured the surrender of British forces in Singapore. Nicholas Tarling stated that the Japanese had showed long-term interest and ambition in South-east Asia. The conquest of Malay Peninsula was completed within a period of seventy days.

Samuel D. Nyam, "Government Policies on the Reclamation and Restoration of Land Devastated by Tin Mining on the Jos Plateau Mines Field from 1900-1990's", PhD Thesis, Department of History, University of Jos, Nigeria, 2000, p. 79.

Ibid.

Monday Y. Mangvwat, A History of Class Formation in the Plateau Province of Nigeria, 19021960, the Genesis of a Ruling Class, Durham, North Carolina: Carolina Academic Press, 2013, p. 124.

Tanya M. Baker, "The Social Organisation of the Berom", PhD Thesis, Department of Anthropology, University of London, November, 1954, p. 18.

A.E. Ekoko, "Conscript Labour and Tin Mining in Nigeria during the Second World War", Journal of the Historical Society of Nigeria, Vol. 11, No. 3/4, December 1982-June 1983, p. 67.

Monday Y. Mangvwat, A History of Class Formation in the Plateau, pp. 101-102.

Ibid., p. 122.

Ibid. 